\title{
Understanding transitions in farming systems and their effects on livestock rearing and smallholder livelihoods in Telangana, India
}

\author{
Bhavana Rao Kuchimanchi ${ }^{D}$, Imke J. M. De Boer, Raimon Ripoll-Bosch, \\ Simon J. Oosting
}

Received: 18 February 2020/Revised: 25 September 2020/Accepted: 22 January 2021/Published online: 8 March 2021

\begin{abstract}
Increasing food demands are causing rapid transitions in farming systems, often involving intensified land and resource use. While transitioning has benefits regarding poverty alleviation and food outputs, it also causes environmental and social issues over time. This study aims to understand the transitions in farming systems in a region in Telangana, from 1997 to 2015, and their effect on livestock rearing and smallholder livelihoods. We also examine the impact of the transitions on lower caste groups and women in particular. We collected data using a combination of methods, i.e., a household survey, focus group discussions, and secondary data sources, to build a comprehensive picture of the transitions in the region. We found that subsistence mixed farming systems transitioned to market-orientated specialized systems over a short time span. As the transition process gained momentum, households either intensified their production or got marginalized. Technological interventions, development programs with integrated approaches, and market demand for certain agricultural produce triggered increased regional production but also led to the scarcity of water, land, and labor. The transitions marginalized some of the households, changed the role of livestock in farming, and have been inclusive of both lower caste groups and women in terms of increased ownership of large ruminants and access to technologies. However, for women specifically, further increase in workload in the context of farming is also found.
\end{abstract}

Keywords Caste groups - Cropping patterns . Dryland regions - Intensification - Land use change · Water resources

\section{INTRODUCTION}

Many developing countries have policies to transition from subsistence farming systems into market-oriented systems in response to the increased demand for animal source food. This transition is often associated with the processes of specialization and intensification of farming systems, as well as increased use of resources, such as biomass, land, and water (Tarawali et al. 2011; Alexandratos and Bruinsma 2012; Bharucha et al. 2014). While such transitions have benefits in terms of increased food output, it may also cause environmental issues, e.g., overexploitation of natural resources, and social issues such as farmer dependency on external inputs and marginalization of communities (Lebacq et al. 2013; Clay et al. 2020).

Agroecosystems in dryland areas, which are predominant regions in developing countries, face harsh agro-climatic conditions and scarce infrastructure and support services, and host diverse farming practices (i.e., pastoral, agropastoral, rainfed, and irrigated crop production). These regions are also hotspots for land degradation, low crop yields, and poverty (van Ginkel et al. 2013; Chander et al. 2014). In India, $69 \%$ of the territory is classified as dryland. To develop these regions socio-economically, several development initiatives have been implemented among which integrated watershed development programs (WDPs) have been and continued to be the forefront strategy (GoI 2008; Smyle et al. 2014). WPDs have resulted in the modernization of farming systems in dryland areas. This meant that traditional mixed crop-livestock farming systems, using local livestock breeds and crops, generally transitioned to more intensive market-oriented and specialized farming systems, using imported breeds and new crop varieties (Puskur et al. 2004; van Ginkel et al. 
2013; Tian et al. 2014; Amjath-Babu and Kaechele 2015; Behera et al. 2016; Gathorne-Hardy 2016). While the transitions in farming systems have increased overall agricultural output (Rao 2000; Government of India 2006; Jhoshi et al. 2008; Wani et al 2008; Palanisami and Kumar 2009), some unfavorable side effects such as the exclusion and marginalization of some social groups (Puskur et al. 2004; Pingali 2012; Kannan 2015), increased workload on women (van Ginkel et al. 2013), and overuse of natural resources (Batchelor et al. 2003; Bharucha et al. 2014) have also been reported.

Development programs like WDPs, which have integrated approaches, are dynamic and known to trigger rapid changes in farming systems that can involve trade-offs and need to be understood further (van Ginkel et al. 2013; Reddy and Syme 2015). Moreover, research on transitions in farming systems is largely focused on farm-level studies (Robinson et al. 2015; Bui et al. 2016; Gaitán-Cremaschi et al. 2019). Regional studies of transitions by Dorward (2013), Jayne et al. (2014), Pretty and Bharucha (2014), and DiCarlo et al. (2018) reported how farming systems developed, how they interact during the transitions, and how the transition affected natural resource use. To our knowledge, there are no scientific publications about regional aspects of transitions in India.

Hence, the aim of this study was to understand the transitions in farming systems in a region in Telangana from 1997 to 2015 that has witnessed over three decades of several development initiatives including WDPs. We look closely at how transitions have occurred and their effect on livestock rearing and smallholder farming systems. We also look at the impact of transitions on different caste groups and women in particular.

\section{MATERIALS AND MATERIALS}

\section{Study location}

In this study, a watershed (WS) is considered as the unit of analysis as it is a part of a larger study that looks at the impact of transitions in farming systems on smallholder livelihoods and the environment. This paper is the first study in the series where the WS is not only considered as a hydrological unit but more as a social-ecological entity, which plays a crucial role in determining food, social, and economic security to rural people (Reddy and Syme 2015). We selected two WSs for the study to understand if the transitions were uniform or if substantial variation existed. WS- 1 is located in Talakondapally Mandal (the smallest administrative unit within a district), covering four villages. WS -2 is in Veldanda Mandal, covering three villages. These Mandals are located in the Rangareddy and Nagarkurnool districts of Telangana State (Fig. 1). The total geographic area of WS-1 is 14120 hectares (ha), and the boundary of the villages under study covered $9463 \mathrm{ha}$. WS-2 spans 13694 ha, with 7701 ha falling within the study village boundary. Hence, for secondary data sources, we considered boundaries of the villages as the secondary data were aligned more with administrative boundaries than with hydrological ones.

Both watersheds fall in the Deccan Plateau (Telangana) and Eastern Ghat agro-ecological sub-region (AESR) 7.2. This sub-region is broadly characterized by deep loamy and clayey mixed red and black soils, with medium to very high available water capacity, and a growing season duration of 120-150 days. The climate is hot and moist in summer and mild and dry in winters, with an aridity index of $0.2 \leq \mathrm{AI}<0.5$ (Rao et al. 2019). Hence, it is classified as a semi-arid region. The districts are drought-prone, with an annual rainfall of $500-700 \mathrm{~mm}$, which follows a seasonal pattern (Gajbhiye and Mandal 2000).

\section{Data collection}

To achieve the aim of this research, we collected data using multiple methods sequentially to build a comprehensive picture of the transitions and their effects on farming HHs in the region. First, we started with a HH survey to obtain an overview of HHs in the region. The HH survey was conducted in both watersheds covering a sample of 3006 HHs. Surveys were face-to-face meetings with the $\mathrm{HH}$ head and were performed using a survey format. The survey provided an overview of information about the population, farm sizes, and categories i.e., large farmers ( $>4$ ha), medium farmers (2-4 ha), small farmers (1-2 ha), and marginal farmers (up to $1 \mathrm{ha}$ ); types of livestock; and different caste groups. The caste system in India is a social hierarchical system that has its origins in ancient India. This system, however, has been transforming since medieval times to several social reforms in modern India today (de Zwart 2000; Bayly 2001). Although several laws exist, stratification continues to exist in various forms. In modern India, the various castes are categorized into 4 main groups, i.e., forward caste (FC), backward caste (BC), scheduled caste (SC), and scheduled tribes (ST), which were also captured through the survey.

Second, using the above data, seven focused group discussions (FGDs) were organized. The objective of the first FGD was to obtain qualitative information on the overall narrative of how transitions occurred in the region pre-1997 to 2015, along with the drivers of change and its impact on HHs in the region. To achieve this, we selected $\mathrm{HHs}$ that had been in the region for the past $30-40$ years. 


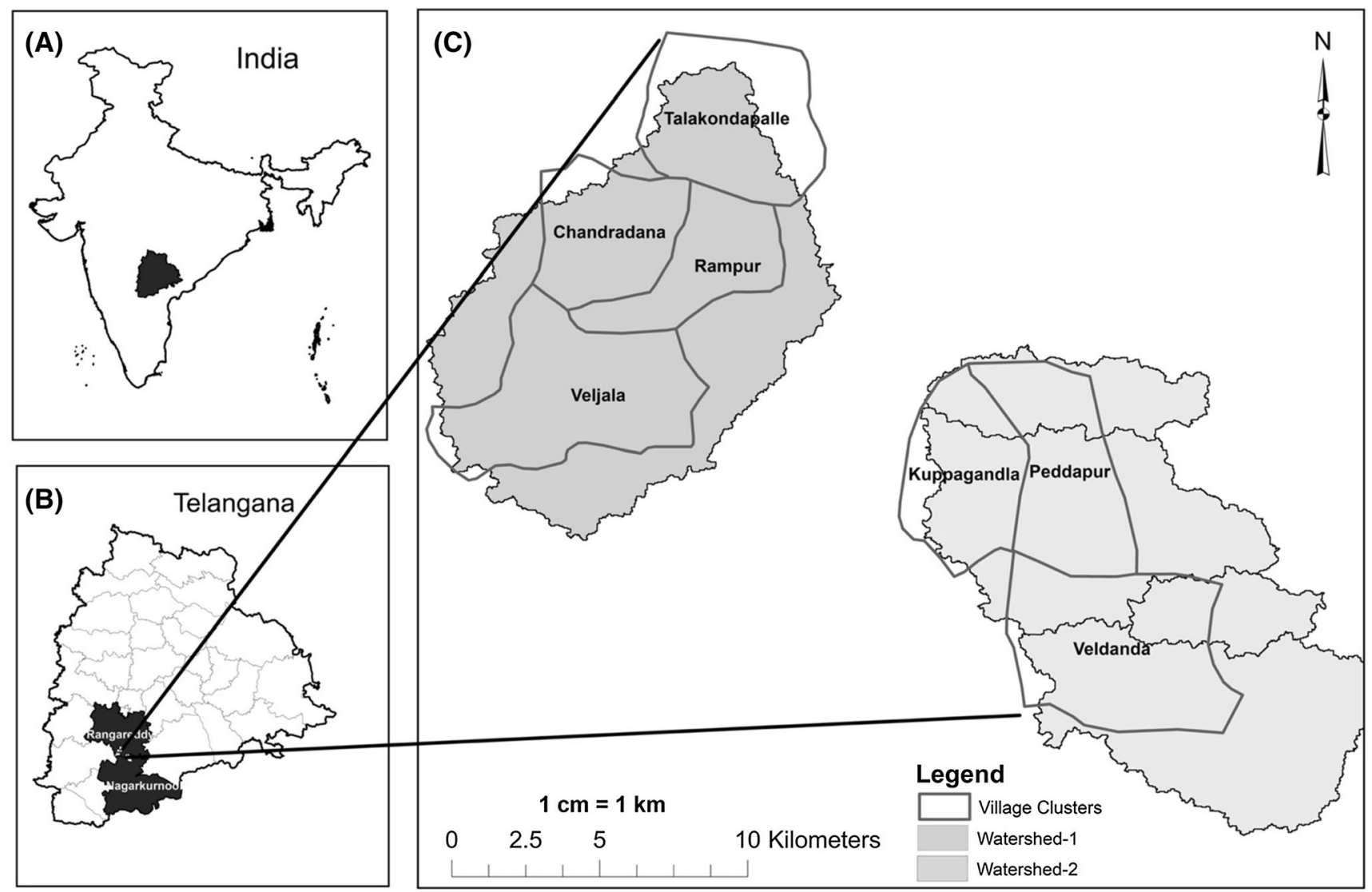

Fig. 1 a Location map of the study region in India. b The study region (districts) within the state of Telangana. c The two watersheds within which the study villages are demarcated. Source: ISRO BHUVAN portal ( htpps://bhuvan.nrsc.gov.in/bhuvan_links.php, accessed 2016)

This was done in consultation with the head of each village council of all study villages. A village council in India is known as a Gram Panchayat, a local self-governance unit. From the list of potential participant $\mathrm{HHs}, 35 \mathrm{HHs}$ were randomly selected and invited for the FGD. Further, we ensured that all farmer categories and caste groups, along with a representation of members of different age categories, i.e., old ( $>60$ years old), middle-aged ( $40-45$ years old), and young $(<25$ years old) were present. If the representation of one of these groups/categories was lacking, we substituted a randomly selected HH from the overrepresented group. This FGD was a mixed-gender group, with a total of 37 participants, of whom only four were women.

This was followed up by organizing the next five FGDs with HHs belonging to different farming system typologies in the region, identified through the $\mathrm{HH}$ survey data (Kuchimanchi et al. unpubl. results). The aim of these FGDs was similar to the first FGD in terms of mapping transitions and understanding their characteristics but with specific reference to the particular farming system. The five farming system typologies were crop without livestock (CWL), crop with dairy $\mathrm{CD}$ ), landless with livestock
(LWL), crop with small ruminants (CSR), and crop with diverse livestock (CWDL). Within each farming system typology, $30 \mathrm{HHs}$ were randomly selected. Adequate representation from all farm size categories and social groups was ensured. These FGDs were again mixed-gender groups, and the actual participation varied from 25 to 30 members per FGD.

Although women participated in all six FGDs, an additional FGD was organized exclusively with women. Owing to socio-cultural reasons, women in India tend to participate in low numbers or do not voice their opinions in mixed-gender meetings. The objective of this FGD was to get a deeper understanding of how transitions affected women with specific reference to farming systems and practices, as transitions in farming systems could have different impacts on both genders. This FGD was organized as part of a monthly women's self-help group meeting in one of the villages, as women of all age groups, castes, and farmer categories are usually present at such meetings. A total of 46 women participated in the FGD.

All seven FGDs lasted for 3-4 h, and the discussions were conducted in the local language, Telugu. For all 
FGDs, a participatory timeline-mapping tool (Hekkert and Negro 2009) supported with a list of questions to guide the discussions was used to achieve the objective of each FGD. The key questions in the FGDs were about major changes in farming systems, crops cultivated, livestock reared, fertilizer usage, livestock products, animal health, fodder resources, land use, and water resources. For the five FGDs specific to farming system typologies, questions related to the characteristics of farming systems and changes within each system were discussed. Concerning the impact on caste groups and women, along with the above, additional questions on aspects related to access to resources and challenges faced due to changes in farming systems were asked.

Considering the diversity in social status, farmer categories, caste, and gender in the FGDs, an experienced facilitator was present to moderate the discussions. The facilitator helped avoid domination by the wealthy, elderly, or socially forward groups and provide adequate time to document information in detail. All the discussions were documented on chart papers to maintain transparency and enhance interaction with the participants. As no major differences in narratives were perceived among FGDs, the documented information from all FGDs was summarized into a macro-picture of how transitions took place in the region, highlighting major aspects across a timeline as illustrated in Table 2. Further, the specific impacts on caste groups and women have also been highlighted in Table 2, in the results section as appropriate and described separately in the subsequent section.

Third, and lastly, to contrast and triangulate the information from the HH survey data and FGDs, we collected secondary government data from both local department offices and online government websites and land use land cover (LULC) evolution in the. The various government data sources consisted of population census 2001, 2011, crop statistics at the sub-district level between 1996 and 2015, the Agriculture at a Glance-Telangana state report 2018, statistics from the Agricultural and Processed Food Products Export Development Authority (APEDA), 2019, and livestock census data for 2007, 2012, the Basic Animal Husbandry Statistics, 2019, and the reports of Central Ground Water Boards published between 1997 and 2020.

For the LULC evolution analysis, land classes identified and mapped in the study area were according to the National Remote Sensing Agency (NRSA 2006) as defined below in brief:

- Settlement area: An area of human habitation that has a cover of buildings and basic infrastructure.

- Cropland-irrigated: Cropland under irrigation or lands that are cropped for two or more seasons in a year, as is often associated with irrigation.
- Cropland-rainfed: Cropland associated with rainfed crops under dryland farming with no irrigation (synonymous with areas with the cropping season-extending between June and October).

- Fallow land: Lands that are cultivated temporarily or kept uncropped for one or more seasons but not less than one year.

- Wasteland: Degraded or underutilized land that is deteriorating for lack of appropriate water and soil management but where key functions can be restored.

- Plantations: Areas under tree crops (agricultural/nonagricultural) planted adopting certain management techniques.

- Water bodies: Areas with surface water, e.g., ponds, lakes, and reservoirs or flowing as streams, rivers, canals, etc.

Agricultural crops in India are grown throughout the year in two main seasons. The LULC maps were combined for both seasons in an annual LULC map for the years 1997, 2005, and 2015. For this, only the total geographic area falling within the village boundaries within both watersheds was considered. Before processing the satellite imagery, a ground-truthing exercise was performed to identify samples of different land classes present in the villages using the global positioning system. Details of the data sources for the satellite imagery used are provided in Table 1.

\section{Calculations and statistical analyses}

We performed statistical tests to understand the impact of transitions on certain parameters (i.e., land and herd size) across caste groups and between watersheds. The statistical analyses were performed using the statistical program GenStat (GenStat Committee 2000) using the HH survey data. First, to compare land sizes and herd sizes of HHs between the watersheds, we used the Mann-Whitney U test because the data were not normally distributed. In these cases, the median and 25th and 75th percentiles are reported. The effect of the watershed and caste of the local communities on the variables land size and herd size was analyzed using the generalized linear model procedure, by the model:

$Y_{i j}=\mu+\alpha_{i}+\beta_{j}=\alpha_{i \times j}+\epsilon_{i j}$,

where $\mathrm{Y}_{\mathrm{ij}}$ is land or herd size per $\mathrm{HH},{ }_{\mathrm{i}}$ is explained by the mean $(\mu)$; watershed $\mathrm{i}\left(\alpha_{\mathrm{i}}\right)$ and caste $\mathrm{j}\left(\beta_{\mathrm{j}}\right)$ are the fixed factors; and $\left(\alpha_{i} \times \beta_{j}\right)$ is the interaction between watershed $\times$ caste, and $\left(\varepsilon_{\mathrm{ij}}\right)$ is the residual error.

Pairwise post hoc comparisons between treatment means were done using Fisher's least significant difference method. Dependent variables showed a skewed distribution 
Table 1 Data sources of satellite imagery used for the LULC study

\begin{tabular}{|c|c|c|c|c|c|}
\hline Study year & Season & Acquisition date & Sensor & $\begin{array}{l}\text { Path } \\
\text { row }\end{array}$ & $\begin{array}{l}\text { Resolution } \\
\text { (m) }\end{array}$ \\
\hline 1997 & $\begin{array}{l}\text { Kharif-monsoon } \\
\text { Rab-winter } \\
\text { Zaid-summer }\end{array}$ & $\begin{array}{l}05 \text { October } 1997 \\
07 \text { \& 20th February } 1997 \\
\text { April } 1997\end{array}$ & $\begin{array}{l}\text { IRS 1C-LISS III-National Remote } \\
\text { Sensing Centre, Hyderabad }\end{array}$ & $100 / 69$ & 30 \\
\hline 2005 & $\begin{array}{l}\text { Kharif-monsoon } \\
\text { Rabi-winter } \\
\text { Zaid-summer }\end{array}$ & $\begin{array}{l}01 \text { September } 2005 \\
17 \text { November } 2005 \\
02 \text { March } 2005\end{array}$ & LANDSAT- Thematic Mapper (TM)-from USGS ${ }^{\mathrm{a}}$ & $144 / 48$ & 30 \\
\hline 2015 & $\begin{array}{l}\text { Kharif-monsoon } \\
\text { Rabi-winter } \\
\text { Zaid-summer }\end{array}$ & $\begin{array}{l}12 \text { October } 2015 \\
17 \text { December } 2015 \\
03 \text { April } 2015\end{array}$ & $\begin{array}{l}\text { LANDSAT Satellite image Operational } \\
\text { Land Imager (OLI) from USGS }{ }^{\mathrm{a}}\end{array}$ & $144 / 48$ & 30 \\
\hline
\end{tabular}

ahttp://glcf.umd.edu/data/landsat/

and were converted to their natural logarithm. To ensure transformation of values of 0 into natural logarithm, we added one unit to all values. Once the tests were run, the mean values and confidence intervals were then backtransformed (Johnson et al. 1994) and subtracted by one unit. Herd size was expressed in tropical livestock units (TLU). The conversion factors were cattle $=0.7 \mathrm{TLU}$, buffalo $=1.5 \mathrm{TLU}$, sheep/goats $=0.1 \mathrm{TLU}$, and poultry $=0.01 \mathrm{TLU}$.

\section{RESULTS}

\section{Transitions in farming systems from 1997 to 2015}

The transition in farming systems described here is a macro-picture of how transitions have occurred in the study region from 1997 to 2015 (Table 2) also with significant events as collected from the HH survey and the various FGDs conducted.

Participants in the first FGD shared that transitions in farming systems started gradually since 1997, with major shifts occurring after the year 2000. Subsistence mixed farming systems were predominant before 1997, and almost all HHs had livestock then. Crop production was mostly rainfed, while livestock farming was grazing-based. Poultry keeping was mainly with indigenous scavenging birds, and every HH had a few. Farming was subsistenceoriented, and only surplus products were sold at local markets. Irrigated crop farming began in the late 1990s when village electrification and borewell technology emerged. Irrigated crops such as cotton, maize, groundnut, vegetables, fruits, and fodder crops like Napier grass (Pennisetum purpureum) and fodder sorghum replaced rainfed food crops such as castor, sunflower, pearl millet, and native variety of sorghum. These trends could be corroborated by crop production data provided by the agriculture department at the sub-district level for WS-2 (data for WS-1 were not available) for the period of 1996-2015. Major changes were seen in a few crops, e.g., the cropped area under sorghum dropped from 1081 ha in $1996-1997$ to 20 ha by $2014-2015$. The cultivation of pearl millet was around $103 \mathrm{ha}$, which completely disappeared by 2015 . Similar trends were found for cotton and maize. In 1996, the area under cotton was 186 ha and no maize was cultivated. By 2015, the area under cotton had increased to 1548 ha and 419 ha, respectively. Vegetable cultivation also increased from just 30 ha in 1996 to 245 ha by 2015 . The area under fodder sorghum increased from 3 to 38 ha in the same period.

In the same FGD, participants further shared that keeping livestock in the pre- $1997^{1}$ period had multiple purposes such as providing food, manure, fuel, and draught power. They mentioned that ownership of good cattle breeds (identified as Ongle, Deoni, Red Sindhi, and $\mathrm{Kr}$ ishna Valley) was linked to having resources in terms of land, water, and finances. Large ruminants were predominantly owned by FCs, while lower caste groups reared small ruminants and poultry. As the mechanization of crop production and motorization of transport increased, the importance of bullocks decreased. Consequently, keeping reproductive cattle to produce bullocks reduced. To this, FGD participants from the CD system added that exotic dairy cattle breeds such as Jersey and Holstein-Friesian started to replace indigenous cattle breeds in 2004 and 2010, respectively. Similar was the case with buffaloes; indigenous buffaloes were replaced by Murrah buffaloes

\footnotetext{
${ }^{1}$ Livestock population trends pre-1997 at village level could not be triangulated with secondary data due to data gaps, hence trends from 2007 to 2012 only have been presented.
} 


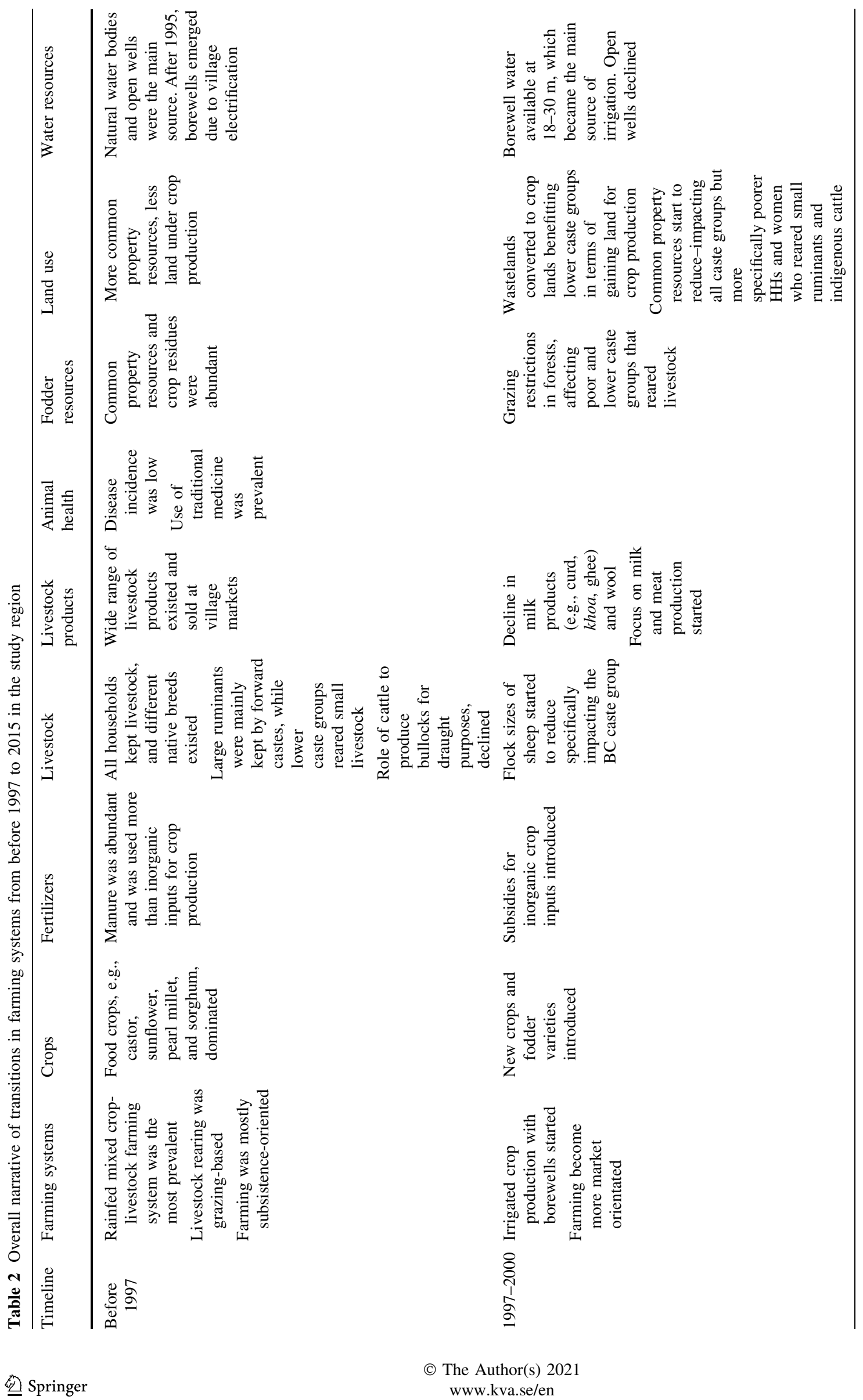




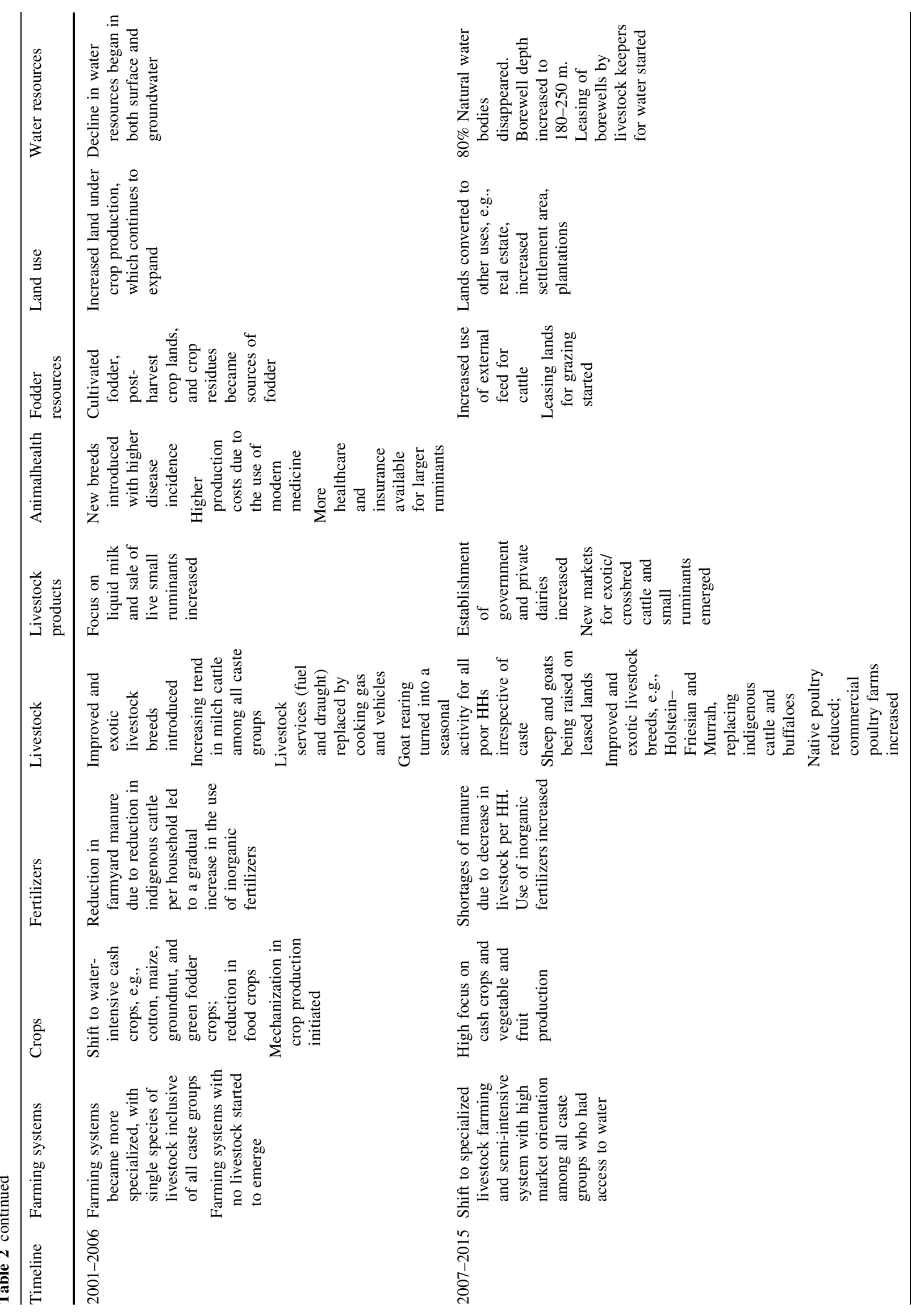

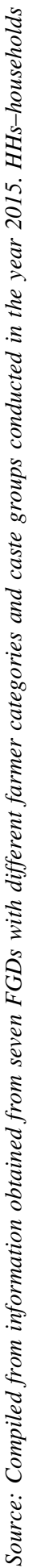


since 2002. This trend described in the FGDs was consistent with the government livestock census reports of 2007 and 2012 at WS level as it indicated a $28 \%$ increase in exotic/crossbred cattle and a decrease in indigenous cattle and buffaloes by $40 \%$ and $38 \%$, respectively. The participants further added that while changes in breeds increased production and subsequently income, disease incidence in livestock is a drawback. Before 1997, animal disease incidence was low, and the diseases were easily cured with traditional medicines. However, with the introduction of exotic breeds, new diseases were reported, and traditional medicines were no longer useful. While animal health services are present, access to these services was reported to be better for large ruminants than for small ruminants. Insurance schemes are also in place but not considered functional by FGD participants due to low accessibility and laborious processing procedures.

In the case of small ruminants, FGD participants from the CSR system mentioned that changes took place both in terms of flock sizes and rearing systems since 1997. Traditionally, sheep were reared by HHs belonging to a livestock-keeping community called Gollas in the state, who are classified as BCs. Sheep rearers in the FGD reported that flock sizes have reduced from 5000 animals per $\mathrm{HH}$ in the past to 100-300 animals per HH. The adjustment in flock sizes was dependent on the availability of grazing lands and labor per $\mathrm{HH}$, both of which have reduced over the years. Hence, more HHs keep sheep now than in the past, albeit in smaller flocks. Sheep migration has also stopped and is resorted to only under severe drought situations. Deccani was the dominant sheep breed pre-1997. This breed has been replaced with the Red Nellore sheep breed from coastal regions since 2000. Sheep farmers indicated that they prefer Red Nellore over Deccani as the former gains weight faster despite fodder scarcity. Participants shared that goats were reared by all caste groups but predominantly by women, poor and landless HHs. The breeds reared were native breeds, of which one was extinct, and could not be identified due to a limited database of local breeds in India. In the past, goat rearing was described as a year-round activity by many HHs. It is now a need-based activity for HHs, often done during the summer season or to cope with crop loss, loan repayment, or a sudden need for money. Government livestock census reports from 2007 to 2012 also report a drop-in sheep population $(-41 \%)$, which could be related to dwindling flock sizes over time, while goat population shows an increase $(26 \%)$ as it has turned into a seasonal activity for many HHs. While a general decrease in livestock population is seen at the $\mathrm{HH}$ level in the region, whether this change increased the economic value per unit is to be researched upon.
Participants in all FGDs indicated that indigenous poultry was kept by all $\mathrm{HHs}$ in the past and was an important source of food and income security for the poor, landless, and women. This trend is also indicated by the livestock census where native poultry rearing showed a drop by $82 \%$ between 2007 and 2012 .

Further, the trends in both crop and livestock production described in all the FGDs do not seem to be limited to the study region but are seen across the state of Telangana. The Basic Animal Husbandry Statistics of 2019 indicate that livestock population changes in the region are similar to trends at the state level except for sheep and goats that show a substantial increase. This could be due to (i) lack of data for the study area before 2007 and (ii) small ruminant populations being linked to the presence of certain caste groups or influenced by HH needs. Similarly concerning the state's cropping patterns, the states' Agriculture at a Glance report indicates a trend towards the cultivation of non-food crops, as the area under food crops came down from 3.39 to 2.62 million ha between 2001 and 2016 .

Further, participants from different farming systems FGDs reported a change in the kind of livestock products being sold, as the demand for raw milk increased. For instance, traditional farm-processed products like curd, buttermilk, khoa (thickened condensed milk), and ghee are not sold by HHs in local markets anymore. This role has been taken over by the government and private dairy units, to which the HHs now supply only raw milk. Moreover, dairy farmers shared that they prefer cows to buffaloes, owing to the better reproductive performance of the former (shorter inter-calving periods), which eventually results in higher income per year. Similar was the case with small ruminants and associated products, particularly for sheep. The demand for wool and other co-products diminished, and sales are currently limited to live animal sale for meat. These trends are aligned with state government data and APEDA, which show a nominal increase in wool production between 2001 and 2015 (i.e., 3.02 to 4.56 million kgs), while the state of Telangana (erstwhile Andhra Pradesh, before 2014) ranks first in sheep production nationally since 2008 .

Lastly, Table 3 reports changes in LULC from 1997 to 2015, which further triangulate data from the FGDs. LULC changes indicated an increase in irrigated and rainfed cropland area by 734 ha and 3693 ha, respectively, mainly at the expense of wastelands, which decreased by 5330 ha. This could be due to an increase in population in the region, as the settlement area has increased from 36 to 475 ha between 1997 and 2015. Further, the reduction in wastelands that were used for grazing livestock resulted in reduced fodder availability for many HHs rearing livestock. This situation worsened further around the year 
Table 3 Changes in land use and land cover from 1997 to 2015 in both watersheds combined

\begin{tabular}{lccc}
\hline Land classification & $\begin{array}{l}\text { LULC 1997 } \\
\text { area (ha) }\end{array}$ & $\begin{array}{l}\text { LULC 2005 } \\
\text { area (ha) }\end{array}$ & $\begin{array}{l}\text { LULC 2015 } \\
\text { area (ha) }\end{array}$ \\
\hline Settlement area & 36 & 253 & 475 \\
Crop land: irrigated & 999 & 2427 & 1733 \\
Crop land: rainfed & 8807 & 7841 & 12500 \\
Plantations & 52 & 612 & 612 \\
Waste land & 7093 & 5925 & 1763 \\
Surface waterbodies & 177 & 105 & 80 \\
& 17164 & 17164 & 17164 \\
\hline
\end{tabular}

Source: Satellite imagery from National Remote Sensing Centre 1997 \& LANDSAT -2005 and 2015 (refer to Table1); LULC area is the area within the village boundaries in both watersheds

2002, and grazing restrictions were also levied on nearby forest areas.

Reduction in access to grazing resources along with a sharp increase in cropland, both irrigated (ca. 75\%) and rainfed (ca. 40\%), not only impacted the availability of fodder for livestock but also livestock rearing in general. Participants from the farming system FGDs shared that currently almost half of the HHs in the villages do not own livestock, also indicated by the HHs survey as $48 \%$. The FGD participants in the CD system stated that dairy producers managed this situation by cultivating perennial fodder crops due to fodder seed subsidies provided by the government and dairy cooperatives. Hence, grazing-based cattle systems eventually changed into semi-stallfed systems, with some grazing on fallow croplands or wastelands if available.

Based on information shared by participants from the crop with small ruminant farming system, it is indicated that small ruminant farming transformed into a modern grazing-based system. Earlier, small ruminants were raised entirely on village common lands or wastelands, with surface water bodies as water sources. Now, cropland, orchards, private lands, and borewells for water are leased to rear small ruminants. According to the participants, sheep rearers could find lands to graze their animals more easily than goat rearers, as goats are browsers, and require lands with tree cover. Goat keepers stated that the availability of wastelands with tree cover has decreased considerably. Hence, goats are now reared in small flocks in seasons when crop farming is low or absent or as per need, rather than as a year-round activity as in the past. Small ruminant rearers added that only HHs that could invest in leasing lands and borewells now continue small ruminant rearing with large flocks as a full-time occupation. The traditional barter systems between small ruminant farmers and crop farmers, where crop residues were bartered against manure, no longer exist.
The participants from all FGDs also stated that while these changes in crop and livestock production took place, water scarcity in the region has also increased. Before 2010, borewells were 18-30 m deep. However, currently, borewells yield water only at $180-250 \mathrm{~m}$ depth. Natural surface water bodies have also disappeared, affecting small ruminant keepers the most, as they now have to invest in buying water for livestock. Both these findings can be corroborated by data from the Central Ground Water Board (2019), as the region has moved from semi-critical to critical status in 2013-2017, indicating the overuse of groundwater. Similarly, the LULC study also indicates that water bodies have reduced by $79 \%$ in the region (Table 3 ).

\section{Impact of transitions on caste groups}

In continuation to the above section, we further analyze the impact of transitions on different caste groups in the study region, particularly to gain insight into differences in land and herd size between castes and watersheds. Figures 2 and 3 present the land and herd sizes of the different caste groups. We found a significant interaction between watersheds and caste groups, which can be mainly explained by the differences observed between watersheds for the ST caste group. We found that the FC communities had the highest land size per HH (2.6 ha) in both watersheds, whereas SC communities in both watersheds had the smallest land sizes (average of $1.0 \mathrm{ha} / \mathrm{HH}$ ). The ST and BC communities had higher land sizes in WS-1 than in WS-2. Similar was the case with herd size, where the FC communities had the highest herd size per HH, except for the STs in WS-1 (average of 2.3 TLUs/HH), followed by the rest. These results align with the information from the FGDs discussed above, wherein land and herd sizes generally still followed the caste hierarchy. However, a change in ownership patterns for large ruminants is observed, in contrast to the past, where lower castes also own dairy cattle.

\section{Impact of transitions on women}

According to the women participants, who attended all FGDs, there were improvements since 2000 regarding access to livestock, livestock ownership, and decisionmaking associated with livestock rearing had increased. This was attributed to the increased participation of women in government-initiated self-help groups in their villages. According to them, participation in self-help groups helped women to gain access to new technologies and own livestock. However, they also reported an increased workload regarding farming and responsibility in terms of loan repayments. With respect to the increase in workload, 


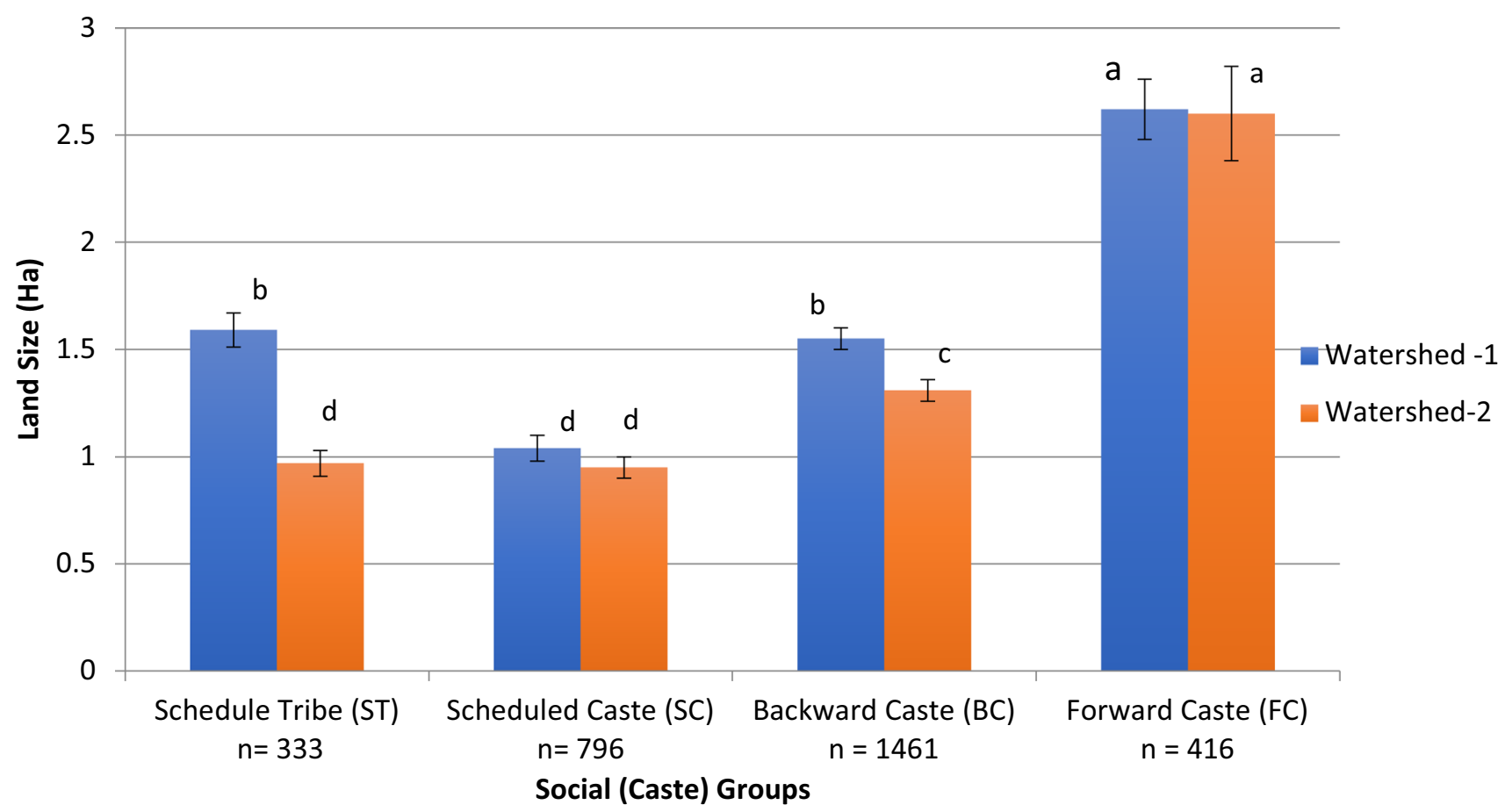

Fig. 2 Land size (in ha) across caste groups (Scheduled tribe, ST; Scheduled caste, SC; Backward caste, BC; and Forward caste, FC) in both watersheds. Source: HHs survey, 2015

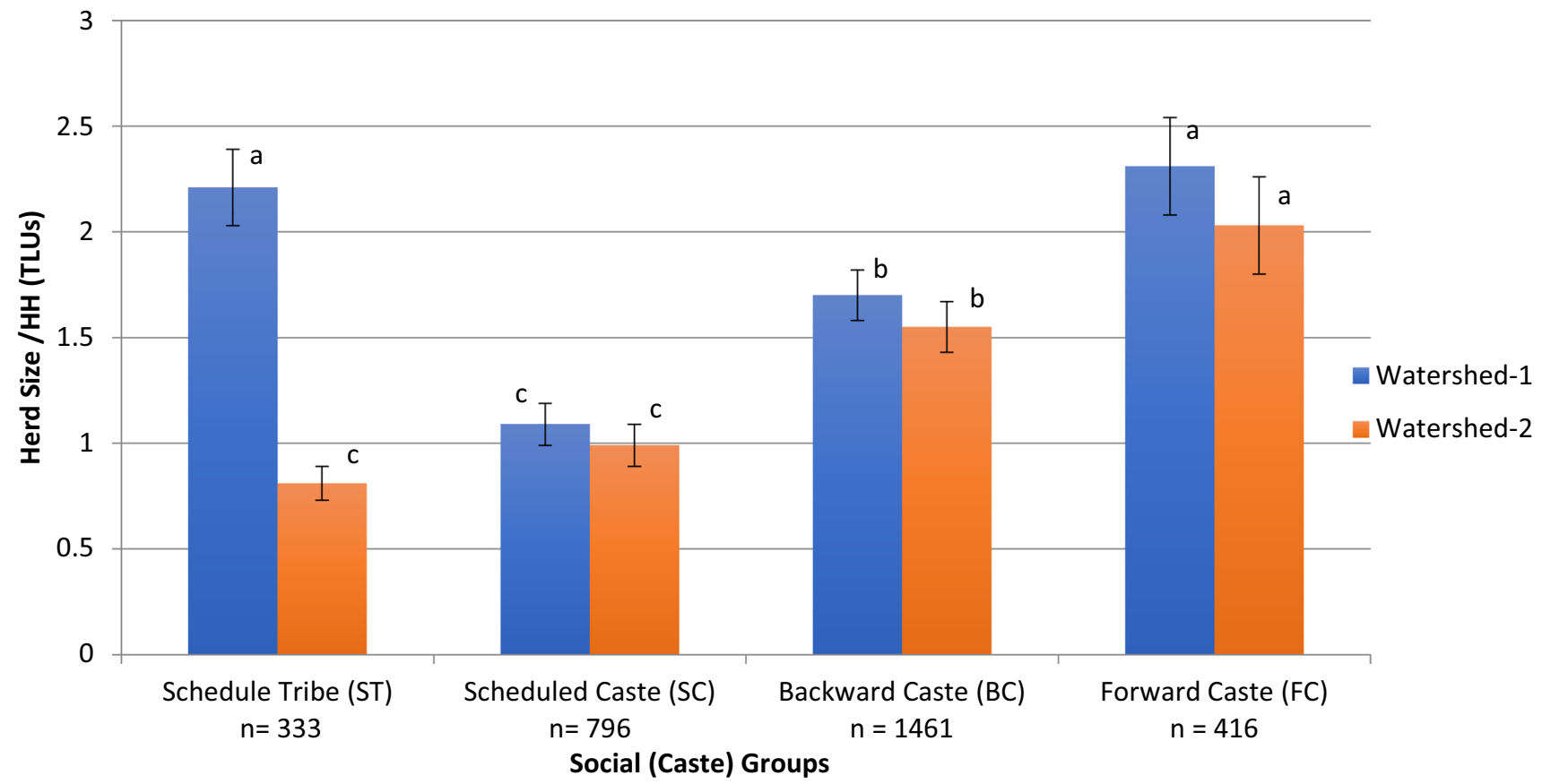

Fig. 3 Herd size (in TLUs) across caste groups (Scheduled tribe, ST; Scheduled caste, SC; Backward caste, BC; and Forward caste, FC) in both watersheds. Source: HHs survey, 2015

women expressed that rearing improved cattle in stallfed systems demanded more time, e.g., for feeding, cleaning sheds, and animal health care, which was limited when compared to rearing cattle in grazing-based systems.
Similar sensitivities were shared by women regarding changes in crop production. For instance, the shift from rainfed food crops to irrigated cash and vegetable crops also increases the workload particularly for tasks from 
multiple harvests to packing, which is carried out exclusively by women.

With regard to the rearing of small livestock, women shared that the rearing of goats and poultry by them has particularly decreased compared to the past. According to them, reduced access to grazing lands and tree cover in the region due to land use changes (Table 3) meant longer grazing hours and hence was avoided by older women and women with young children. Meanwhile, the reduction in native poultry rearing was due to developments in settlement areas and closer proximity of houses within the settlement areas, which led to reduced scavenging areas for chickens and conflicts among HHs.

\section{DISCUSSION}

\section{Characteristics of transition}

Our study aimed at describing transitions in farming systems at a regional scale and analyzing their impacts on livestock rearing and smallholder livelihoods, along with insights on caste groups and women. The findings from the FGDs, HH survey data, LULC data (Table 3), and statistical tests (Figs. $2 \& 3$ ) all indicated that trends of how the transitions in farming systems occurred in both watersheds were similar. They were completely in the direction of market orientation and happened in a relatively short period. Matthei and Smith (2008) and Butler et al. (2014) show that such transitions are possible despite the diversity of social groups within a region. Here, community aspirations to improve living standards tend to overcome the social and cultural identities bringing in flexibility to adapt to changing circumstances. Farming systems before 1997 were mostly subsistence-oriented, with mixed crop-livestock production and livestock having diverse functions (Ali 2007; Kumar and Singh 2008). Between 1997 and 2015, the subsistence farming system disappeared, and specialized and market-oriented production systems emerged. The multiple roles of livestock in mixed farming systems reduced to the role of food production mainly. In these new systems, the investments, cost of production, and input use have become relatively high, e.g., inputs for cultivating cash crops, leasing land for grazing livestock or growing fodder, leasing or drilling borewells for water, farm mechanization, purchase of feed, and animal healthcare (Singh et al. 2014; Gathorne-Hardy 2016; Ghosh et al. 2017; Kuchimanchi et al. unpubl. results). Further, these changes do not seem to be limited to the study region as similar trends in changes in agricultural landscapes, livestock holdings, and cropping patterns are reported in Telangana (Reddy et al. 2016) and across India (Government of India 1997, 2002, 2007, 2012; Amjath-Babu and
Kaechele 2015; Behera et al. 2016). Such a relatively fast and region-wide transition from subsistence farming to market-oriented farming has also been reported in Africa, Latin America, and Asia by Reardon et al. (2019).

\section{Drivers of transition}

The transitions in farming systems from 1997 to 2015 in the two watersheds were driven by technological interventions, development programs promoting green and white revolution technologies with integrated approaches, and increased market demand for cash crops and certain livestock products (Behera et al. 2016; Gathorne-Hardy 2016). An important technological intervention that triggered the transition process is village electrification, which prompted the use of motor pumps for extracting water from borewells, thereby facilitating water-intensive crop and livestock production (Tian et al. 2014). Further, we find that the sudden increase in water availability in dryland regions, due to the development programs with integrated approaches, e.g., watershed development, seemed to be a lucrative incentive for smallholders to adopt new technologies and diversify faster (van Ginkel et al. 2013) facilitating rapid transitions in farming systems.

The major market for the study region is Hyderabad, one of the biggest cities in India, growing from 3.6 million inhabitants in 2001 to 11.5 million in 2018. While the population growth in itself was an important reason for the increased demand, the income growth of the urban population also adds to this by influencing changes in food consumption patterns (Oosting et al. 2014; Kumar et al. 2017; Van der Lee et al. 2018; Reardon et al. 2019). Hyderabad has the highest food consumption expenditure per month in Telangana, of which the highest share comprises animal products (32\% of the total) (Kumar et al. 2017), indicating a huge and possibly growing demand in this sector.

While FGDs identified several drivers that triggered the transitions, this is not an exhaustive list. Other drivers might have also played an important role, such as the influence of external policy situation, input of remittances, or differences in education and knowledge gains between castes or gender (Thompson et al. 2007; Reardon et al. 2019). The contribution of these other aspects to farming systems transitions needs further study.

\section{Impacts of the transitions in farming systems on smallholder livelihoods}

While transitions in farming systems across India and the study watersheds might be beneficial in some ways, however, not all is positive (George 1986, 2014; Pingali 2012; Hinz et al. 2020). Programs with integrated approaches, 
e.g., WDPs make development dynamic and involve tradeoffs as well (van Ginkel et al. 2013). For example, the transitions in the study region favored the expansion of croplands, increased use of green revolution technologies, and more focus on milk production. It also reduced the production of other livestock products, reduced diversity within farming systems, and eroded animal genetic diversity. This is a trend generally reported in the literature in transitions from subsistence to market-oriented farming systems (Puskur et al. 2004; Jayne et al. 2014; van Ginkel et al. 2013; Oosting et al. 2014; Gathorne-Hardy 2016).

Further, increased production by some farmers in the study area has triggered regional changes in water, land, and labor scarcity for others, making it compulsory for all to intensify production. The transition, therefore, was not a free process but a compulsory adaptation, inclusive of social and cultural differences due to changing circumstances (Matthei and Smith 2008). This can be inferred because the HHs without agricultural activities or with the traditional subsistence mixed farming system together is around $10 \%$ in both watersheds. This implies that once the transition process gained momentum, farmers could either join in or step out from agriculture, and is in line with Dorward et al. (2009) and Reardon et al. (2019). An additional marginalization was also witnessed in our study watersheds: we observed that only a limited fraction (38\%) of HHs could maintain both crop and dairy cattle, while half of the $\mathrm{HHs}$ (48\%) did not rear livestock owing to inadequate water resources, which is already a problem in dryland regions. This dramatic change further implies that the majority of the HHs are susceptible to risk due to the lack of diversification at the $\mathrm{HH}$ level, particularly the absence of livestock. The lack of crop-livestock integration may also have negative implications on agricultural production and revenue in the long term (Kuchimanchi et al. unpubl. results). Increasing water scarcity in the region as reported by the respondents is also in line with Sishodia et al. (2016) and the Central Ground Water Board's report (2017), which indicates a decrease in groundwater levels both within the study region and across the state.

Despite the considerable increase in cropland area, land size per $\mathrm{HH}$ has likely reduced over time due to fragmentation of land, e.g., by the division of property among siblings, as both settlement area and $\mathrm{HH}$ population (Government of India 2001, 2011) in the watersheds show an increase by $12.2 \%$ and $16 \%$, respectively. This trend seems to be across the state; the agricultural statistics report of Telangana (2016) shows that the average landholding in the state in $2010-11$ was 1.12 ha against the all-India average of 1.16 ha. Hence, it is likely that many HHs in the study region have become marginalized during the transition process and have migrated, changed their occupations, or become wage laborers.

\section{Effect on caste groups and women}

Many of the approaches of the green and white revolutions are still being out-scaled through development policies and programs as a means of poverty alleviation, e.g., integrated WDPs, self-help group movements, or agricultural subsidies and schemes. In this context, the transitions in the two watersheds showed that lower caste groups now own improved cattle (Figs. 2 and 3) and have consequently moved up the livestock ladder (Udo et al. 2011). We also found some exceptions where the STs in WS-1 had both land and herd sizes as high as those of the FCs. These changes among lower caste groups can be attributed to several government-sponsored schemes (Reddy et al. 2016) which are specifically designed for their upliftment (Government of India 2008). Nevertheless, our study shows that FCs continue to own the largest land sizes and cattle herd sizes, as in the past.

The transition towards intensification and market orientation was women-inclusive, as women had increased access to technologies, information, and livestock resources. However, a perceived increase in workload for women was reported in our study which in line with other studies in India (Vepa 2005; van Ginkel et al. 2013; Pattnaik et al. 2017). In this case, this was in the form of the shift from grazing-based livestock rearing to stallfed market-oriented systems (Köhler-Rollefson 2012) and from rainfed food crops to irrigated cash and vegetable crops. This perception of increased workload existed as certain activities in croplivestock production are predominantly done by women, along with the already existing traditional roles within the home (Lastarria-Cornhiel and Bank 2008). Furthermore, a general reduction in small livestock rearing and poultry rearing by women is seen, depriving them of potential activities to gain financial and nutritional security (Conroy et al. 2005; Chatterjee and Rajkumar 2015).

\section{CONCLUSIONS}

Studying transitions in farming systems at a regional level highlighted various interactions in the study region, i.e., between diverse farming systems, between farming system development and natural resource use, and between regional transition and different social groups. We demonstrate how these elements impacted the development trajectory of a region with a dual effect of both enhanced incomes and marginalization of some farming $\mathrm{HHs}$ therein.

We found that the regional transitions in farming systems have occurred in a short period, and subsistence mixed farming systems have almost completely transformed into market-orientated specialized systems in the region. Further, the function of livestock in farming 
changed from a multi-purpose role in the past to a marketoriented food production role. The major drivers of the transitions were found to be technological interventions, development programs with integrated approaches, and market demand for certain agricultural produce. While the transitions led to increased production by some HHs, they also led to the scarcity of water, land, and labor for others. The transition, therefore, was not a free process but a compulsory adaptation, inclusive of social and cultural differences among the HHs in the region. The HHs had to either intensify production to adapt to the transforming prospects or get marginalized. The implications of these transitions were progressive in the case of lower caste groups, as they have moved up the livestock ladder and gained assets. However, in the case of women, it was perceived unfavorable in terms of increased workloads and reduced food and financial security. Our study, thus, provides deeper insights into how transitions impact multiple aspects of smallholder livelihoods. Finding from this study could contribute to the strengthening of rural development policies to reduce risks in agricultural production, e.g., water scarcity stemming from already operational programs.

Acknowledgements This research did not receive any specific grant from funding agencies in the public, commercial, or not-for-profit sectors. The author would like to thank Watershed Organization Trust (WOTR) for allowing the research to be carried out in their project villages in Telangana, India, and Vijayasekaran Duraisamy PhD. for technical support in the LULC study using GIS. The author would like to extend a special thanks to Editor-in-Chief Bo Söderström and the two anoymous reviewers for their indepth review that led to shaping this paper significantly.

Open Access This article is licensed under a Creative Commons Attribution 4.0 International License, which permits use, sharing, adaptation, distribution and reproduction in any medium or format, as long as you give appropriate credit to the original author(s) and the source, provide a link to the Creative Commons licence, and indicate if changes were made. The images or other third party material in this article are included in the article's Creative Commons licence, unless indicated otherwise in a credit line to the material. If material is not included in the article's Creative Commons licence and your intended use is not permitted by statutory regulation or exceeds the permitted use, you will need to obtain permission directly from the copyright holder. To view a copy of this licence, visit http://creativecommons. org/licenses/by/4.0/.

\section{REFERENCES}

Alexandratos, N., and J. Bruinsma. 2012. World agriculture towards 2030/2050: the 2012 revision. ESA Working paper No. 12-03. Rome, FAO.

Ali, J. 2007. Livestock sector development and implications for rural poverty alleviation in India. Livestock Research for Rural Development 19.
Amjath-Babu, T.S., and H. Kaechele. 2015. Agricultural system transitions in selected Indian states: What do the related indicators say about the underlying biodiversity changes and economic trade-offs? Ecological Indicators 57: 171-181.

APEDA. 2019. Agri-exchange portal, sheep production data 2007 to 2019. Retrieved 1 August 2020, from http://apeda.in/ agriexchange/India\%20Production/India_Productions.aspx?cat= LiveStock\&hscode $=1025$.

Bayly, S. 2001. Caste, Society and Politics in India from the Eighteenth Century to the Modern Age. Cambridge: Cambridge University Press.

Behera, R.N., D.K. Nayak, P. Andersen, and I.E. Måren. 2016. From jhum to broom: Agricultural land-use change and food security implications on the Meghalaya Plateau, India. Ambio 45: 63-77.

Batchelor, C.H., M.S Ram Mohan Rao, and S. Manohar Rao. 2003. Watershed development: A solution to water shortages in semiarid India or part of the problem? Land Use and Water Resources Management 3: 1-10.

Bharucha, Z.P., D. Smith, and J. Pretty. 2014. All paths lead to rain: Explaining why watershed development in India does not alleviate the experience of water scarcity. Journal of Development Studies 50: 1209-1225.

Bui, S., A. Cardona, C. Lamine, and M. Cerf. 2016. Sustainability transitions: Insights on processes of niche-regime interaction and regime reconfiguration in agri-food systems. Journal of Rural Studies 48: 92-103.

Butler, J.R.A., W. Suadnya, K. Puspadi, Y. Sutaryono, R.M. Wise, T.D. Skewes, D. Kirono, E.L. Bohensky, et al. 2014. Framing the application of adaptation pathways for rural livelihoods and global change in eastern Indonesian islands. Global Environmental Change 28: 368-382.

Central Ground Water Board. 2017. National Compilation on Dynamic Ground Water Resources of India, Government of India, Ministry of Jal Shakti. Government of India: River Development \& Ganga Rejuvenation.

Central Ground Water Board. 2019. Ground Water Yearbook Telangana State, Ministry of Jal Shakti. Government of India: River Development \& Ganga Rejuvenation.

Chatterjee, R.N., and U. Rajkumar. 2015. An overview of poultry production in India. Indian J. Anim. Hlth. 54: 89-108.

Clay, N., T. Garnett, and J. Lorimer. 2020. Dairy intensification: Drivers, impacts and alternatives. Ambio 49: 35-48.

Chander, G., P.S. Wani, L.K. Sahrawat, B.S. Dixit, B. Venkateswarlu, C. Rajesh, P. Narsimha Rao, and G. Pardhasaradhi. 2014. Soil test-based nutrient balancing improved crop productivity and rural livelihoods: case study from rainfed semi-arid tropics in Andhra Pradesh, India. Archives of Agronomy and Soil Science 60: 1051-1066.

Conroy, C., N. Sparks, and D. Chandrasekaran. 2005. Improving Backyard Poultry-keeping: A case study from India. Agricultural Research and Extension Network 146: 1-16.

DiCarlo, J., K. Epstein, R. Marsh, and I. Måren. 2018. Post-disaster agricultural transitions in Nepal. Ambio 47: 794-805.

de Zwart, F. 2000. The logic of affirmative action: Caste, class and quotas in India. Acta Sociologica 43: 235-249.

Dorward, A. 2013. Agricultural labour productivity, food prices and sustainable development impacts and indicators. Food Policy 39: $40-50$.

Dorward, A., S. Anderson, Y.N. Bernal, E.S. Vera, J. Rushton, J. Pattison, and R. Paz. 2009. Hanging in, stepping up and stepping out: Livelihood aspirations and strategies of the poor. Development in Practice 19: 240-247.

FAO. 2011. The State of Food and Agriculture, Women In Agriculture - Closing the gender gap for development, Food and Agriculture Organization of the United Nations Rome, 2011 
Gajbhiye, K.S. and C. Mandal. 1983. Agro-Ecological Zones, their Soil Resource and Cropping Systems, Status of Farm Mechanization in India, pp. 1-32.

Gathorne-Hardy, A. 2016. The sustainability of changes in agricultural technology: The carbon, economic and labour implications of mechanisation and synthetic fertiliser use. Ambio 45: 885-894.

George, J. 1986. White Revolution in India: Myth or Reality? Economic and Political Weekly 21: 2147-2150.

George, T. 2014. Why crop yields in developing countries have not kept pace with advances in agronomy. Global Food Security 3: 49-58.

Ghosh, N., A. Tripathi, M. Rajeshwor, and R. Singh. 2017. Do producers gain from selling milk, Economic and Political Weekly, LII n25 26 (June 24, 2017), pp. 88-96.

Gaitán-Cremaschi, D., L. Klerkx, J. Duncan, J.H. Trienekens, C. Huenchuleo, S. Dogliotti, M.E. Contesse, and W.A.H. Rossing. 2019. Characterizing diversity of food systems in view of sustainability transitions: A review. Agronomy for Sustainable Development. Paris: Springer.

Government of India. 1996-2015.Yearly Crop Data at village level from 1996 to 2015. Department of Agriculture-Sub-district level, Telangana, India.

Government of India. 1997. 16th Indian Livestock Census. New Delhi, India: Department of Animal Husbandry and Fisheries Ministry of Agriculture.

Government of India. 2001. Census of India District Census Handbook - Mehabubnagar Directorate of Census. Andhra Pradesh, India: Operations.

Government of India. 2002. 17th Indian Livestock Census. New Delhi, India: Department of Animal Husbandry and Fisheries Ministry of Agriculture.

Government of India. 2006. Report of the Technical Committee on Watershed Programmes in India: From Hariyali to Neeranchal. New Delhi: Department of Land Resources Ministry of Rural Development, Department of Land Resources.

Government of India. 2007. 18th Indian Livestock Census Indian Livestock Census. New Delhi, India: Department of Animal Husbandry and Fisheries Ministry of Agriculture.

Government of India. 2008. Common guidelines for watershed development projects-revised edition-2011 National Rainfed Area Authority, Planning Commission \& Departments of Land Resources. Retrieved 25 August, 2019, from https://dolr.gov.in/ documents/guidelines.

Government of India. 2011. Census of India District Census Handbook - Mehabubnagar. Andhra Pradesh, India: Directorate of Census Operations.

Government of India. 2012. 19th Indian Livestock Census. New Delhi, India: Department of Animal Husbandry and Fisheries Ministry of Agriculture.

Government of Telangana. 2016. Agriculture at a Glance-Telangana (2015-16). Hyderabad, India: Directorate of Economics and Statistics, Planning Department.

Government of Telangana. 2018. Agriculture at a Glance-Telangana -2017. Hyderabad, India: Directorate of Economics and Statistics, Planning Department.

Government of India. 2019. Basic Animal Husbandry Statistics. Department of Animal Husbandry and Dairying, Ministry of Fisheries, Animal Husbandry, and Dairying, New Delhi, India.

Hekkert, M.P. and S.O. Negro. 2009. Technological Forecasting \& Social Change Functions of innovation systems as a framework to understand sustainable technological change: Empirical evidence for earlier claims. Technological Forecasting \& Social Change 76: 584-594.

Hinz, R., T.B. Sulser, R. Huefner, D. Mason-D'Croz, S. Dunston, S. Nautiyal, C. Ringler, J. Schuengel, et al. 2020. Agricultural development and land use change in India: A scenario analysis of trade-offs between UN Sustainable Development Goals (SDGs). Earth's Future

Jayne, T.S., J. Chamberlin, and D.D. Headey. 2014. Land pressures, the evolution of farming systems, and development strategies in Africa: A synthesis. Food Policy 48: 1-17.

Johnson, N.L., S. Kotz, and N. Balakrishna. 1994. Continuous Univariate Distributions, vol. 1, 2nd ed. New York: Wiley.

Joshi, P.K., A.K. Jha, S.P. Wani, T.K. Sreedevi, and F.A. Shaheen. 2008. Impact of Watershed Program and Conditions for Success: A Meta-Analysis Approach. Global Theme on Agroecosystems Report no. 46. Monograph. International Crops Research Institute for the Semi-Arid Tropics, Patancheru, Andhra Pradesh, India.

Kannan, E. 2015. Trends in agricultural incomes: An analysis at the select crop and state levels in India. Journal of Agrarian Change 15: 201-219.

Kohler-Rollefson, I. 2012. Invisible guardians: Women manage livestock diversity. FAO Animal Production and Health Paper No. 174. Rome, Italy.

Kumar, A., and D.K. Singh. 2008. Livestock production systems in India: An appraisal across agro-ecological regions. Indian Journal of Agricultural Economics 63: 577-597.

Lastarria-Cornhiel, S. and W. Bank. 2008. Feminization of Agriculture: Trends and Driving Forces, Background Paper for The World Development Report 2008.

Lebacq, T., P.V. Baret, and D. Stilmant. 2013. Sustainability indicators for livestock farming. A review. Agronomy for Sustainable Development 33: 311-327.

Matthei, L.M., and D.A. Smith. 2008. Flexible ethnic identity, adaptation, survival, resistance: The Garifuna in the worldsystem. Social Identities 14: 215-232.

National Remote Sensing Agency. 2006. National Land Use and Land Cover Mapping Using Multi-Temporal AWiFS Data National Land Use and Land Cover Mapping Using Multi-Temporal AWiFS Data.

Oosting, S.J., H.M.J. Udo, and T.C Viets. 2014. Development of livestock production in the tropics: Farm and farmers' perspectives. Animal. Cambridge: Cambridge University Press.

Palanisami, K. and Suresh Kumar, D. 2009. Impacts of Watershed Development Programmes: Experiences and Evidences from Tamil Nadu. Agricultural Economics Research Review 22: 387-396.

Pattnaik, I., K. Lahiri-Dutt, S. Lockie, and B. Pritchard. 2017. The feminization of agriculture or the feminization of agrarian distress? Tracking the trajectory of women in agriculture in India. Journal of the Asia Pacific Economy. https://doi.org/10. 1080/13547860.2017.1394569.

Pingali, P.L. 2012. Green Revolution: Impacts, limits, and the path ahead. Proceedings of the National Academy of Sciences 109: 12302-12308.

Pretty, J. and Z.P. Bharucha. 2014. Sustainable intensification in agricultural systems. Annals of Botany 1911.

Puskur, R., J. Bouma, and C. Scott. 2004. Sustainable livestock production in semi-arid watersheds. Economic and Political Weekly 39: 3477-3483.

Rao, C.H. 2000. Watershed development in India: Recent experiences and emerging issues. Economic and Political Weekly 35: 3943-3947.

Ramarao, M.V.S., J. Sanjay, R. Krishnan, M. Mujumdar, A. Bazaz, and A. Revi. 2019. On observed aridity changes over the semiarid regions of India in a warming climate. Theoretical and Applied Climatology 136: 693-702.

Ratna Reddy V., and G.J. Syme. 2015. Integrated assessment of scale impacts of watershed intervention: Assessing hydrogeological and bio-physical influences on livelihoods/ISBN: 978-0 12-800067-0. Elsevier Inc. 
Reardon, T., R. Echeverria, J. Berdegué, B. Minten, S. LiverpoolTasie, D.Tschirley, and D. Zilberman. 2019. Rapid transformation of food systems in developing regions: Highlighting the role of agricultural research \& innovations. Agricultural Systems 172: $47-59$.

Reddy, A.A., C.R. Rani, T. Cadman, T.P. Reddy, M. Battarai, and A.N. Reddy. 2016. Rural transformation of a village in Telangana, a study of Dokur since 1970s. International Journal of Rural Management 12: 143-178.

Robinson, L.W., P.J. Ericksen, S. Chesterman, and J.S. Worden. 2015. Sustainable intensification in drylands: What resilience and vulnerability can tell us, Agricultural Systems 135: 133-140.

Sanjiv Kumar, S., A. Ranjit Kumar, N. Dhandapani, P.C. Meena. Sivaramane, and P. Radhika. 2017. Food Consumption Pattern in Telangana State-2017. Hyderabad, India: ICAR-National Academy of Agricultural Research Management.

Smyle, J., C. Lobo, G. Milne, and M. Williams. 2014. Watershed Development in India: An Approach Evolving through Experience, Agriculture and Environmental Services discussion paper 0 4. The International Bank for Reconstruction and Development/ The World Bank.

Singh, D., B. Sanjay Kumar, Singh and D. Bardhan. 2014. Economic losses due to important diseases of bovines in central India. Veterinary World 7: 403-407.

Sishodia, R.P., S. Shukla, D. Wendy Graham, S.P Wani, and K.K. Garg. 2016. Bi-decadal groundwater level trends in a semi-arid south indian region: Declines, causes and management. Journal of Hydrology: Regional Studies 8 : 43-58.

Tarawali, S., M. Herrero, K. Descheemaeker, E. Grings, and M. Blümmel. 2011. Pathways for sustainable development of mixed crop livestock systems: Taking a livestock and pro-poor approach. Livestock Science 139: 11-21.

Tian, H., K. Banger, D. Bo Tao, K. Vinay. 2014. History of land use in India during 1880-2010: Large-scale land transformations reconstructed from satellite data and historical archives. Global and Planetary Change 121: 78-88.

Thompson, J., E. Millstone, I, Scoones, A. Ely, F.Marshall, E.Shah, and S. Stagl. 2007. Agri-food System Dynamics: Pathways to sustainability in an era of uncertainty, STEPS Working Paper 4, Brighton: STEPS Centre

Udo, H.M.J., H.A. Aklilu, L.T. Phong, R.H. Bosma, I.G.S. Budisatria, B.R. Patil, and B.O. Bebe. 2011. Impact of intensification of different types of livestock production in smallholder croplivestock systems. Livestock Science 139: 22-29.

Van Der Lee, J., L. Klerkx, B.O. Bebe, A. Mengistu, and S.J. Oosting. 2018. Intensification and upgrading dynamics in emerging dairy clusters in the East African highlands. Sustainability (Switzerland) 10: 1-24.

van Ginkel, M., J. Sayer, F. Sinclair, A. Aw-Hassan, D. Bossio, P. Craufurd, M. El Mourid, N. Haddad, et al. 2013. An integrated agro-ecosystem and livelihood systems approach for the poor and vulnerable in dry areas. Food Security 5: 751-767.
Vepa, S.S. 2005. Feminisation of agriculture and marginalisation of their economic stake. Economic and Political Weekly 40: $2563-2568$

VSN International. 2019. Genstat for Windows, 20th ed. Hemel Hempstead, UK: VSN International.

Wani, S P., P.K. Joshi, K.V. Raju, T.K. Sreedevi, J.M. Wilson, A. Shah, P.G. Diwakar, K. Palanisami, et al. 2008. Community Watershed as a Growth Engine for Development of Dryland Areas: A Comprehsive Assessment of Watershed Programs in India. Global Theme on Agroecosystems. Report No. 47. International Crops Research Institute for the Semi-Arid Tropics and Ministry of Agriculture and Ministry of Rural Development, New Delhi.

Publisher's Note Springer Nature remains neutral with regard to jurisdictional claims in published maps and institutional affiliations.

\section{AUTHOR BIOGRAPHIES}

Bhavana Rao Kuchimanchi $(\square)$ is a doctoral candidate at the Animal Production Systems Group, Wageningen University \& Research. She is also associated with the Foundation for Ecological Security, a national-level NGO in India as a research consultant. Her research interests include sustaining rural livelihoods in relation to crop-livestock production.

Address: Animal Production Systems Group, Wageningen University \& Research, P.O. Box 338, 6700 AH Wageningen, The Netherlands. Address: Foundation for Ecological Security, Jahagir Pura Road, Hadgood, Anand, Gujarat 388110, India.

e-mail: bhavanarln@gmail.com

Imke J. M. De Boer is a professor of the Animal Production Systems group of Wageningen University. Her research interests include sustainability assessment of animal production systems, the role of livestock in a circular economy and in nutrition security.

Address: Animal Production Systems Group, Wageningen University \& Research, P.O. Box 338, 6700 AH Wageningen, The Netherlands.

Raimon Ripoll-Bosch is a researcher at the Animal Production Systems group of Wageningen University. His research interests include ecosystem services and biodiversity in relation to livestock production.

Address: Animal Production Systems Group, Wageningen University \& Research, P.O. Box 338, 6700 AH Wageningen, The Netherlands.

Simon J. Oosting is an associate professor at the Animal Production Systems group of Wageningen University. His field of research is tropical livestock production systems and tropical livestock nutrition. Address: Animal Production Systems Group, Wageningen University \& Research, P.O. Box 338, 6700 AH Wageningen, The Netherlands. 